\title{
Spectral, Electrochemical and Molecular Orbital Studies on a New Solvatochromic Binuclear Mixed Ligand Copper(II) Complexes
}

\section{Taha A and Ahmed HM*}

Faculty of Education, Ain Shams University, Roxy, Cairo, Egypt

\begin{abstract}
A new series of solvatochromic binuclear mixed ligand complexes with the general formula: Cu2(DMCHD)(Am)2X3 (where, DMCHD: 5.5-Dimethyl cyclohexanate 1,3-dione, Am=N,N,N'-trimethylethylenediamine (Me3en), N,N,N',N'tetramethylethylenediamine (Me4en), or N,N,N',N',N"-penta-methyldiethylenetriamine (Me5dien) and $\mathrm{X}=\mathrm{ClO} 4-$ or $\mathrm{Cl}$ have been synthesized and characterized by the analytical, spectral methods, magnetic and molar conductance as well as electrochemical measurements. The formation constant values for HDMCHD ligand with various metal ions are much lower than expected for similar $\beta$-diketones revealing a monobasic unidentate nature of this ligand. The $d$-d absorption bands of the prepared complexes in weak donor solvents suggest square-planar, distorted octahedral and/ or distorted trigonal bipyramid geometries for the perchlorate and chloride of diamine in addition to triamine complexes, respectively. However, an octahedral structure was identified for the complexes in strong donor solvents. Perchlorate of diamine complexes show a remarkable color change from violet to green as the Lewis basicity of the donor solvent or anions increases, whereas chloride complex is mainly affected by the Lewis acidity of the acceptor solvent. Specific and non-specific interactions of solvent molecules with the complexes have been investigated using the unified solvation model. Band's oscillator strength of the $d-d$ transition has been calculated and discussed. Cyclic voltammetric measurements on the prepared complexes in different solvents showed a quasi-reversible or irreversible and mainly diffusion controlled reduction process. Such behavior has been explained according to the EECE mechanism. A linear correlation has been found between the $\mathrm{Cu}$ (II) reduction potential and the spectral data. Structural parameters of the free ligands and their $\mathrm{Cu}(\mathrm{II})$ - complexes have been calculated on the basis of semiemperical PM3 level and correlated with the experimental data.
\end{abstract}

Keywords: Formation constant; pH-metric; Solvatochromic; Red shift; Oscillator strength; Cyclic voltammetry; Semiemperical; Molecular modeling; Biological activity

\section{Introduction}

Solvatochromism is widely used in many fields of chemical and biological research to study bulk and local polarity in macro-systems (membranes, etc.), even though its wide use, solvatochromism (a color change as a result of solvent effect) still remains a largely unknown phenomenon due to the enormously complex coupling of many different interactions and dynamical processes which describe it. Metal- chelates with $\mathrm{O}_{2} \mathrm{~N}_{2}$ as Schiff-base or mixed ligands have been studied as solvatochromic indicators [1-5]. In view of the limited information available regarding the spectroscopic properties of mixed ligand metal complexes containing 5.5-dimethyl cyclohexane1,3dione (HDMCHD) the present study which is a continuation of our studies on chromotropic of the metal chelates with mixed ligands containing $\mathrm{O}-\mathrm{O}$ and $\mathrm{N}-\mathrm{N}$ in various solvents [6-10]. In the preceding communication detailed structural, molecular orbital and optical characterizations of solvatochromic mixed ligand copper(II) complex of 5,5-dimethyl cyclohexanate 1,3-dione and N,N,N',N',N'-pentamethyldiethylenetriamine, $\mathrm{Cu}(\mathrm{DMCHD})\left(\mathrm{Me}_{5}\right.$ dien $) \mathrm{NO}_{3}$, the structure elucidated as mononuclear and HDMCHD ligand acted as mono-basic monodentate [11].

Thus, the purpose of the current work was to achieve a microscopic understanding of the intermolecular effects which govern the absorption spectral properties of solvated complex probes, such as solubility, Lewisacid base, and specific and non-specific interactions. Thus, the present investigation includes: (a) effect of solvent anion and secondary ligand (polyamine) on energetic shifts of $\mathrm{d}$-d bands and change the color of solution, (b) solvation effect on the structure and stability of the resulting complexes. For this intention a new series of copper(II) complexes abbreviated as $\mathrm{Cu}_{2}(\mathrm{DMCHD})(\mathrm{Am})_{2} \mathrm{X}_{3}$ (where $\mathrm{DMCHD}=5$.5-dimethyl cyclohexanate1.3-dione, $\quad \mathrm{Am}=\mathrm{N}, \mathrm{N}, \mathrm{N}$-trimethylethylenediamine $\left(\mathrm{Me}_{3} \mathrm{en}\right), \quad \mathrm{N}, \mathrm{N}, \mathrm{N}^{\prime}, \mathrm{N}^{\prime}$-tetramethylethylenediamine $\left(\mathrm{Me}_{4} \mathrm{en}\right), \quad$ or
$\mathrm{N}, \mathrm{N}, \mathrm{N}^{\prime}, \mathrm{N}^{\prime} \mathrm{N}^{\prime}$-pentamethyldiethylenetriamine $\left(\mathrm{Me}_{5}\right.$ dien $)$ and $\mathrm{X}=\mathrm{ClO}_{4}$ or $\mathrm{Cl}^{-}$have been synthesized and characterized by spectral, conductivity and magnetic as well as electrochemical techniques. The main goal of this study is to examine the applicability of the current complexes as a Lewis acid-base color indicator. As further support to our experimental work, molecular orbital calculations have been accomplished using Hyperchem 7.52 for the ligands and their complexes, the structural parameters data are correlated with the experimental results.

\section{Experimental}

\section{Materials}

All chemicals used were of the analytical reagent grade and obtained from either Merck or Aldrich and were used without further purification. Solvents used, nitromethane $\left(\mathrm{CH}_{3} \mathrm{NO}_{2}\right)$, acetonitrile $(\mathrm{MeCN})$, acetone $\left(\mathrm{Me}_{2} \mathrm{CO}\right)$, methanol $(\mathrm{MeOH})$, pyridine (py), $\mathrm{N}, \mathrm{N}$-dimethylformamide (DMF) and dimethylsulfoxide (DMSO), propylenedicarbonate (PDC), formamide $(\mathrm{Fa})$ were "Spectro-grade" and further purified using standard methods [12].

\section{Physical measurements}

The infrared spectra in $\mathrm{KBr}\left(400-4000 \mathrm{~cm}^{-1}\right)$ were recorded using Shimadzu FTIR 8101 spectrometer. Electronic spectra were obtained on UV-2101 pc w/full spectrophotometer using $10 \mathrm{~mm}$ quartz cells

*Corresponding author: Ahmed HM, Faculty of Education, Ain Shams University Roxy, Cairo, Egypt, Tel: 202-268-312-31; E-mail: hany_magdy2013@yahoo.com

Received May 20, 2015; Accepted June 25, 2015; Published June 30, 2015

Citation: Taha A, et al. (2015) Spectral, Electrochemical and Molecular Orbital Studies on a New Solvatochromic Binuclear Mixed Ligand Copper(II) Complexes. Mod Chem appl 3: 158. doi:10.4172/2329-6798.1000158

Copyright: ( 2015 Taha A, et al. This is an open-access article distributed under the terms of the Creative Commons Attribution License, which permits unrestricted use, distribution, and reproduction in any medium, provided the original author and source are credited. 
thermostated at $25^{\circ} \mathrm{C}$. Magnetic moments were obtained using a MSB-AUTO magnetic susceptibility balance by the Gouy method. The molar conductance was measured with Metrohm 660 conductor in $\mathrm{DMF}$ solutions at $25^{\circ} \mathrm{C}$. The potentiometric titrations were carried out by means of a digital 520 WTW pH-meter with a conventional $\mathrm{pH}$-electrode. Titrations and calculations of the proton-dissociation and stepwise formation constants were performed as described earlier [12]. Cyclic voltammetric measurements were performed as reported elsewhere $[8,13]$.

\section{Syntheses of $\mathrm{Cu}_{\mathrm{n}}(\mathrm{DMCHD})(\mathrm{Am})_{\mathrm{n}} \mathrm{X}_{\mathrm{m}}$ complexes}

These complexes were prepared by adding a mixture of $10 \mathrm{mmol}$ of the HDMCHD ligand in $25 \mathrm{~mL}$ absolute EtOH and solid anhydrous $\mathrm{Na}_{2} \mathrm{CO}_{3}(20 \mathrm{mmol})$ to an ethanolic solution of $20 \mathrm{mmol}$ appropriate copper(II) salt. The mixture was continuously stirred for about 30 minutes resulting in a green solution, which was then filtered. Then a solution of $20 \mathrm{mmol}$ diamine or triamine derivative $(\mathrm{Am})$ in $20 \mathrm{~mL}$ EtOH was added dropwise to the filtrate with a continuous stirring for an additional $45 \mathrm{~min}$. After that, the resulting solution was filtered off and left to stand overnight. The complexes obtained were re-crystallized from dichloromethane and stored over silica gel.

\section{Results and Discussion}

The analytical and physical data of the mixed ligands solid complexes with $\mathrm{Cu}(\mathrm{II})$ ion are given in Table 1. It is well known that most of $\beta$-diketones are mixtures of keto-enol forms. Their keto-enol tautomerism is responsible for the formation of inner complexes with metal ions; so they behave in general as monobasic bidentate nature [14]. This statement cannot apply to characterize the current mixed ligands complexes of copper(II) with 5,5-dimethylcyclohexane1,3dione (HDMCHD) and polyamine ligands (Am). This motivated us to study the complexation equilibrium of HDMCHD ligand with various metal ions in solution to focus the light on the dentate nature of HDMCHD ligand. Thus, poteniometric titration studies were carried out for HDMCHD ligand with various metal ions in $50 \%(\mathrm{v} / \mathrm{v})$ aqueous solution.

\section{Potentiometric studies}

Potentiometric titration curves of free HDMCHD ligand $\left(2.5 \times 10^{-3}\right.$ $\mathrm{M})$ in the absence and presence of different metal ions $\left(5 \times 10^{-4} \mathrm{M}\right)$ in a ratio 5:1(L:M) revealed: (i) divalent metal ions showed a distinct inflection point at $m=2,(m=$ number of moles of base added per mole of metal ion), indicating the formation of $\mathrm{ML}_{2}$, (ii) however an inflection at $\mathrm{m}=3$ for trivalent metal ions corresponding to the formation of $\mathrm{ML}_{3}$ or $\mathrm{ML}_{2} \mathrm{OH}$ complexes.
The titration curve of the free ligand against $\mathrm{KOH}$ solution shows one ionizable proton as expected with the value of $\mathrm{pK}^{\mathrm{H}}=6.29$ and 6.16 , in $50 \%(\mathrm{v} / \mathrm{v})$ dioxane-water and isopropanol-water, respectively which agrees with the value obtained in pure water $\left(\mathrm{pK}^{\mathrm{H}}=5.22\right)$ [15]. The trend of deprotonation constant is in the opposite of increasing dielectric constant of the medium. The lower basicity of HDMCHD compared to acetylacetone arises from the existence of $95.3 \%$ of HDMCHD in enol form $[15,16]$.

Formation constants values given in Table 2 , evident that $\log \mathrm{K}_{1}$ and $\mathrm{K}_{2}$ values are too low compared to the basicity of HDMCHD ligand [17]. Moreover allied complexes derived from 2-acylcyclohexanone have sufficiently large formation constant values supporting its bidentate nature. These facts in addition to the small ratio of the two successive formation constants would lead to suggest monodentate nature of HDMCHD. Furthermore, the half-chair boat [18] conformation of the enol form of HDMCHD clearly depicts that due to imposition of the planar configuration of the cyclohexane ring bearing the groupings $-\mathrm{C}(\mathrm{OH})=\mathrm{C}-\mathrm{C}=\mathrm{O}$ the proximity of the $\mathrm{C}-\mathrm{OH}$ and $\mathrm{C}=\mathrm{O}$ groups (the positions of which are non-flexible) are so wide that intramolecular hydrogen bonding is precluded in HDMCHD. Thus chelation is not possible, rather complex formation would take place typically by the replacement of the hydrogen ion of the enolic-OH group [15]. Thus, HDMCHD ligand behaves as monobasic mono-dentate or binuclear bidentate ligand.

The values in Table 2 reveal that, the formation constants increase in the following order: $\mathrm{Cd}(\mathrm{II})<\mathrm{Mn}(\mathrm{II})<\mathrm{Co}$ (II) $\sim \mathrm{Ni}(\mathrm{II})<\mathrm{Cu}(\mathrm{II})<<\mathrm{Fe}$ (III) This order except $\mathrm{Fe}$ (III) (owing to the higher oxidation state) is largely reflects the change in the heat of complex formation across the series, which arises from a combination of the influence of the polarizing ability of metal ion and crystal field stabilization energies [12]. The formation constant values of some lanthanides $\left(\operatorname{Ln}^{3+}\right)$-DMCHD complexes increase in the order of increasing $1 / \mathrm{r}$ ( $\mathrm{r}=$ ionic radii of $\mathrm{Ln}(\mathrm{III})$ ions): $\operatorname{Pr}(\mathrm{III})<\mathrm{Sm}(\mathrm{III})<\mathrm{Yb}(\mathrm{III})$.

\section{Infrared spectra}

The main characteristic IR absorption frequencies of the free ligand (HDMCHD) and its $\mathrm{Cu}(\mathrm{II})$-mixed ligand complexes are given in Table 3. The observed bands may classified into those originating from the ligands, those emanating from the counter-balancing anions and those arise from the bonds formed between copper(II) and coordinating sites. The bands are assigned in comparison with similar $\mathrm{Cu}(\mathrm{II})$-complexes [7-11,19]. The broad band observed in the range $3225-3520 \mathrm{~cm}^{-1}$ for complex (1) assigned to $v_{\mathrm{NH}}$ of the unsymmetrical alkylated diamine $\mathrm{Me}_{3}$ en- ligand. The blue shift of the observed IR absorption bands at

\begin{tabular}{|c|c|c|c|c|c|c|c|c|c|c|}
\hline \multirow{2}{*}{ No. } & \multirow{2}{*}{$\begin{array}{l}\text { Complex } / \\
\text { Emperical Formula }\end{array}$} & \multirow{2}{*}{$\begin{array}{l}\text { Formula } \\
\text { weight }\end{array}$} & \multirow{2}{*}{ Color } & \multicolumn{4}{|c|}{ Anal, Found (Calc) } & \multirow[b]{2}{*}{ M.P } & \multirow{2}{*}{$\begin{array}{l}\mathrm{N} / \mathrm{S} . \mathrm{cm}^{2} \\
\mathrm{Mol}^{-1}\end{array}$} & \multirow{2}{*}{$\begin{array}{l}\text { Meff. } \\
\text { (B.M) }\end{array}$} \\
\hline & & & & $\mathbf{M} \%$ & $\mathrm{C} \%$ & $\mathrm{H} \%$ & $\mathbf{N} \%$ & & & \\
\hline 1 & $\begin{array}{c}\mathrm{Cu}_{2}(\mathrm{DMCHD})\left(\mathrm{Me}_{3} \mathrm{en}\right)_{2}\left(\mathrm{ClO}_{4}\right)_{3} \cdot 2 \mathrm{C}_{2} \mathrm{H}_{5} \mathrm{OH} \\
\mathrm{C}_{22} \mathrm{H}_{51} \mathrm{~N}_{4} \mathrm{O}_{16} \mathrm{Cl}_{3} \mathrm{Cu}_{2}\end{array}$ & 861 & Bluish violet & $\begin{array}{r}15.25 \\
(14.75)\end{array}$ & $\begin{array}{c}31.42 \\
(30.69)\end{array}$ & $\begin{array}{r}5.98 \\
(5.97)\end{array}$ & $\begin{array}{r}6.46 \\
(6.51)\end{array}$ & 196 & 199 & 1.65 \\
\hline 2 & $\begin{array}{c}\mathrm{Cu}_{2}(\mathrm{DMCHD})\left(\mathrm{Me}_{4} \mathrm{en}\right)_{2}\left(\mathrm{ClO}_{4}\right)_{3} 2 \mathrm{C}_{2} \mathrm{H}_{5} \mathrm{OH} \\
\mathrm{C}_{24} \mathrm{H}_{53} \mathrm{~N}_{4} \mathrm{O}_{16} \mathrm{Cl}_{3} \mathrm{Cu}_{2}\end{array}$ & 889 & Reddish-violet & $\begin{array}{c}17.80 \\
(14.30)\end{array}$ & $\begin{array}{c}32.5 \\
(32.39)\end{array}$ & $\begin{array}{c}5.90 \\
(5.96)\end{array}$ & $\begin{array}{l}6.21 \\
(6.29)\end{array}$ & 154 & 245 & 1.74 \\
\hline 3 & $\begin{array}{c}\mathrm{Cu}_{2}(\mathrm{DMCHD})\left(\mathrm{Me}_{4} \text { en }\right)_{2} \mathrm{Cl}_{3} \cdot 2 \mathrm{C}_{2} \mathrm{H}_{5} \mathrm{OH} \\
\mathrm{C}_{24} \mathrm{H}_{55} \mathrm{~N}_{4} \mathrm{O}_{4} \mathrm{Cl}_{3} \mathrm{Cu}_{2}\end{array}$ & 697 & Green & $\begin{array}{c}19.02 \\
(18.22)\end{array}$ & $\begin{array}{c}41.70 \\
(41.35)\end{array}$ & $\begin{array}{r}7.68 \\
(7.95)\end{array}$ & $\begin{array}{l}7.43 \\
(8.04)\end{array}$ & 110 & 90 & 2.67 \\
\hline 4 & $\begin{array}{c}\mathrm{Cu}_{2}(\mathrm{DMCHD})\left(\mathrm{Me}_{5} \mathrm{dien}\right)_{2}\left(\mathrm{ClO}_{4}\right)_{3} \\
2 \mathrm{C}_{2} \mathrm{H}_{5} \mathrm{OH} \\
\mathrm{C}_{30} \mathrm{H}_{69} \mathrm{~N}_{6} \mathrm{O}_{16} \mathrm{Cl}_{3} \mathrm{Cu}_{2}\end{array}$ & 1003 & Reddish-violet & $\begin{array}{l}12.01 \\
11.61\end{array}$ & $\begin{array}{c}37.25 \\
(37.22)\end{array}$ & $\begin{array}{l}8.19 \\
(7.66)\end{array}$ & $\begin{array}{l}7.78 \\
(7.66)\end{array}$ & 157 & 155 & 1.62 \\
\hline
\end{tabular}

Table 1: Physical and analytical data of $\mathrm{Cu}_{2}(\mathrm{DMCHD})(\mathrm{am})_{2} \mathrm{X}_{\mathrm{m} 3}$ complexes. 
Citation: Taha A, Ahmed HM (2015) Spectral, Electrochemical and Molecular Orbital Studies on a New Solvatochromic Binuclear Mixed Ligand Copper(II) Complexes. Mod Chem appl 3: 158. doi:10.4172/2329-6798.1000158

Page 3 of 8

\begin{tabular}{|c|c|c|c|c|c|c|c|c|c|}
\hline \multirow{3}{*}{ Cation } & \multicolumn{6}{|c|}{ HDMCHD } & \multirow{2}{*}{\multicolumn{3}{|c|}{ Hacac }} \\
\hline & \multicolumn{3}{|c|}{ Dioxane-water } & \multicolumn{3}{|c|}{ Isopropanol-water } & & & \\
\hline & LogK1 & LogK2 & $\log \beta$ & LogK1 & LogK2 & $\log \beta$ & LogK1 & LogK2 & $\log \beta$ \\
\hline $\mathrm{H}^{+}$ & 6.29 & - & - & 6.16 & - & - & 11.78 & - & 7.27 \\
\hline $\mathrm{Mn}^{+2}$ & 3.45 & 3.11 & 6.56 & - & - & - & 4.18 & 3.07 & - \\
\hline $\mathrm{Co}^{+2}$ & 3.64 & 3.22 & 6.86 & 3.52 & 3.13 & 6.65 & 5.40 & 4.40 & - \\
\hline $\mathrm{Ni}^{+2}$ & 3.62 & 3.21 & 6.83 & 3.62 & 3.21 & 6.83 & 6.69 & 6.73 & - \\
\hline $\mathrm{Cu}^{+2}$ & 3.62 & 3.33 & 6.95 & 3.49 & 3.15 & 6.64 & 8.22 & 8.23 & - \\
\hline $\mathrm{Cd}^{+2}$ & 3.43 & 3.07 & 6.50 & 3.51 & 3.11 & 6.62 & 3.82 & 2.76 & - \\
\hline $\mathrm{Fe}^{+3}$ & 6.12 & 5.87 & 11.99 & 5.62 & 5.41 & 11.03 & - & - & - \\
\hline $\mathrm{Pr}^{+3}$ & 3.58 & 3.20 & 6.78 & 3.39 & 3.07 & 6.46 & - & - & 2.64 \\
\hline $\mathrm{Sm}^{+3}$ & 3.69 & 3.28 & 6.97 & 3.48 & 3.13 & 6.61 & 5.59 & 4.46 & 2.86 \\
\hline $\mathrm{Yb}^{+3}$ & 3.74 & 3.34 & 7.08 & 3.65 & 3.26 & 6.91 & 5.18 & 4.86 & - \\
\hline
\end{tabular}

Table 2: Stability constants of metal ccomplexes of 5,5-dimethyl cyclohexane 1,3-dione (HDMCHD) $25^{\circ} \mathrm{C}(\square=0.10$ in 50 (v/v) $\%$ solvent - water)

1613 and $1582 \mathrm{~cm}^{-1}$ in the spectrum of free HDMCHD ligand which assigned to $v(\mathrm{C}=\mathrm{O})$ to $1624-1674$ and $1598-1618 \mathrm{~cm}^{-1}$, respectively suggest the involvement of the carbonyl group in the coordination sphere of $\mathrm{Cu}(\mathrm{II})$ [19].

The coordination modes of perchlorate anion have been implied from the IR data. Two intense stretching vibrational bands at 1140 and $625 \mathrm{~cm}^{-1}$ are observed for the perchlorate complexes 1,2 and 4. the weak splitting observed for the strong broad band of $v_{(\mathrm{CIO} 4)}$ at $1140 \mathrm{~cm}^{-1}$ indicates a mixture modes for perchlorate anions, properly one being partially contributing to the coordination sphere of $\mathrm{Cu}(\mathrm{II})$ as bidentate, and the other being free [7-11,19].

\section{Conductance measurements}

The molar conductance values, in DMF $\left(10^{-3} \mathrm{~mol} / \mathrm{L}\right)$, of all complexes are given in Table 1 . These values indicate that all complexes in DMF showed an electrolyte behavior, which might arises to the Lewis basicity of DMF that drive out the coordinating anions, especially when the Lewis basicity of anion (such as $\mathrm{ClO}_{4}$ ) is much weaker than DMF solvent [20]. Complexes 1, 2 and 4 have molar conductance values 199, 245 and $155 \mathrm{ohm}^{-1} \mathrm{~cm}^{2} \mathrm{~mol}^{-1}$, respectively indicating 1:3 electrolyte [21]. Whereas, complex 3 has molar conductivity value $90 \mathrm{ohm}^{-1} \mathrm{~cm}^{2}$ $\mathrm{mol}^{-1}$, suggesting the ionic nature of complex 3 (1:1 electrolytes).

\section{Electronic spectra}

The prepared complexes are freely soluble in most organic solvents and their UV/Vis spectra were measured at room temperature in a variety of solvents, selected to give a wide spread of donor and acceptor strengths as possible; the data obtained are collected in Table 4. The positions of the $\mathrm{d}-\mathrm{d}$ absorption band of the $\mathrm{Cu}_{2}(\mathrm{DMCHD})(\mathrm{Am})_{2} \mathrm{X}_{3}$, where $\mathrm{X}=$ perchlorate or chloride anions in weak donor solvent (such as $\mathrm{CH}_{3} \mathrm{NO}_{2}$ ) are observed in the range $19.05 \times 10^{3}$ and $14.47-$ $13.97 \times 10^{3} \mathrm{~cm}^{-1}$. These values could be assigned to the following $\mathrm{d}-\mathrm{d}$ transitions: $\mathrm{dxy} \mathrm{dx}^{2}-\mathrm{y}^{2}\left({ }^{2} \mathrm{~B}_{1 \mathrm{~g}} \rightarrow{ }^{2} \mathrm{~B}_{2 \mathrm{~g}}\right), \mathrm{dx}^{2}-\mathrm{y}^{2} \rightarrow \mathrm{dz}^{2}\left({ }^{2} \mathrm{E}_{\mathrm{g}} \rightarrow{ }^{2} \mathrm{~T}_{2 \mathrm{~g}}\right)$, and $/$ or $\mathrm{dz}^{2} \rightarrow \mathrm{dx}^{2}-\mathrm{y}^{2}[22,23]$. These transitions suggest a square planar for diamine perchlorate complexes 1 and 2; distorted octahedral for triamine perchlorate complex 4 and/or square based pyramidal distorted trigonal bipyramide (SBRDTBP) geometries for chloride complex $3[24,25]$. This could be attributed to the polyamine, which varies between diamine for complexes 1-3 and triamine in complex 4 , and coordination abilities of anions towards $\mathrm{Cu}(\mathrm{II})$. This interpretation further confirmed by the strong effect of anions on the d-d bands of perchlorate complexes 1 and 2 in weak donor solvents such as $\mathrm{MeNO}_{2}$ (Table 5). The red shift of $v_{\max }$ versus the donor strength of these anions $\left(D N_{X, \mathrm{MeNO}_{2}}\right)$ [20] yield the following linear correlations: $v_{\max } / \mathrm{cm}^{-1}=20340-168.44 D N_{X, M e N O_{2}} \mathrm{r}=0.99$, and $v_{\max } / \mathrm{cm}^{-1}=18640-$
125.28, $D N_{X}, \mathrm{CH}_{3} \mathrm{NO}_{2} \mathrm{r}=0.95$, for $\mathrm{Cu}_{2}\left(\mathrm{Me}_{3} \mathrm{en}\right)_{2}(\mathrm{DMCHD})\left(\mathrm{ClO}_{4}\right)_{3}$ and $\mathrm{Cu}_{2}\left(\mathrm{Me}_{4} \text { en }\right)_{2}(\mathrm{DMCHD})\left(\mathrm{ClO}_{4}\right)_{3}$, respectively.

The position of the $\mathrm{d}-\mathrm{d}$ transition band of diamine perchlorate complexes 1 and 2 exhibits a red shift forming a wide range of color solutions (violet $\rightarrow$ blue $\rightarrow$ green) as the Lewis basicity of solvent increases revealing a positive solvatochromic [9]. Figure 1 shows the visible absorption spectra of the $\mathrm{Cu}_{2}(\mathrm{DMCHD})\left(\mathrm{Me}_{4} \text { en }\right)_{2}\left(\mathrm{ClO}_{4}\right)_{3}$ complex 2, in different organic solvents. There is only one broad band observed in the visible region that assigned to the promotion of an electron from $\mathrm{dz}^{2}$ orbital of the $\mathrm{Cu}$ (II) ion to the hole in $\mathrm{dx}^{2}-\mathrm{y}^{2}$ orbital of the $\mathrm{Cu}(\mathrm{II})$ ion $\left(\mathrm{d}^{9}\right)$ forming different distorted tetragonal depending on the Lewis basicity (DN) of the donor solvent or anion [23]. This red shift could be attributed to the strong repulsion of the electrons in $\mathrm{dz}^{2}$ orbital by the lone pair of the incoming Lewis base such as solvent molecules or anion species, those are axially coordinated to the central copper (II) ion, consequently, a less energy will be required to transfer the electron to $d x^{2}-y^{2}$. In view of the fact that all the $d_{x y}, d_{y z}$ and $d_{x z}$ orbitals of the $\mathrm{Cu}(\mathrm{II})$ ion are raised up by its interaction with the lone pair of electron on the solvent molecules approaching from above and below of the molecular plane, the broad d-d transition band of complexes moves gradually to the red with the increase of the Lewis basicity (DN) of the solvent. This originates in variation of Lewis acidbase interaction between the complex ion and the respective solvent molecules or anion.

Some remarks on the solute-solvent interaction resolved from the data in Table 4 are of immediate notes with discussing., (a) the $\lambda_{\max }$

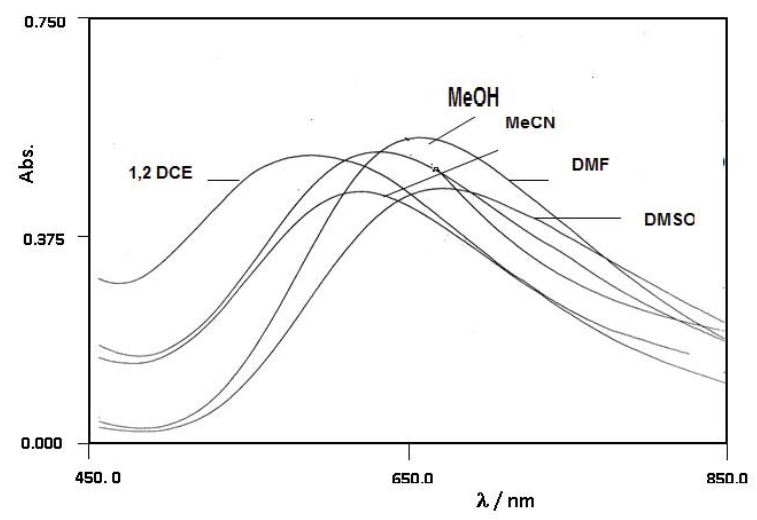

Figure 1: Electronic absorption spectra of $2.39 \times 10^{-3} \mathrm{~mol} \mathrm{Cu}_{2}(\mathrm{dim})$ $\left(\mathrm{Me}_{4} \text { en }\right)_{2}\left(\mathrm{ClO}_{4}\right)_{3} \mathrm{O}$ complex, two solutions in various organic solvents at $25^{\circ} \mathrm{C}$. 
of the present complexes in 1,2-dichloroethane (DCE) occur at longer wavelength than in nitro methane $\left(\mathrm{CH}_{3} \mathrm{NO}_{2}\right)$, although the donor number of DCE $(\mathrm{DN}=0)$ is lower than that of $\mathrm{CH}_{3} \mathrm{NO}_{2}(\mathrm{DN}=2.7)$. This anomaly was ascribed to the formation of ion pairs by mean of an axial coordination of $\mathrm{ClO}_{4}$ anion in DCE. As the relative dielectric constant of nitromethane 28.5 versus 8.9 for DCE at room temperature; facilitating the dissociation of cationic complex and minimizes the axial interactions of $\mathrm{ClO}_{4}$ - with the central copper(II) ion [26]. (b) Finally, although donor strength (DN), of acetone is higher than that of acetonitrile, the solutions of the present perchlorate of diaminecomplexes 1 and 2 in acetone show a slightly lower ${ }_{\text {max }}$ values than acetonitrile solution. This discrepancy was recognized to the effect of steric and $\pi$-bonding in acetone and acetonitrile, since they are acting in opposite directions [27].

The extraction of chemical information from the data in Table 4 can be carried out by statistical method of Multiple Linear Regression Analysis (MLRA). In this method, a dependent variables $\mathrm{Y}\left(v_{\max }\right)$ is described in terms of a series of explanatory variables X. In this respect, the well known Gutmann's and Mayer's donor-acceptor numbers (DN and AN) [28] and the unified solvation model of Drago [29-31] were used, according to Equations 1 and 2; respectively.

$$
\begin{aligned}
& v_{\max } / 10^{3} \mathrm{~cm}^{-1=} v^{0}+\mathrm{a}(\mathrm{DN})+\mathrm{b}(\mathrm{AN}) . \\
& v_{\max } / 10^{3} \mathrm{~cm}^{-1=} \mathrm{W}+\mathrm{P}(\mathrm{S})+\mathrm{E}_{\mathrm{B}} \mathrm{E}_{\mathrm{A}}+\mathrm{C}_{\mathrm{B}} \mathrm{C}_{\mathrm{A}}
\end{aligned}
$$

It is assumed that all the explanatory variables are independent of each other and truly additive as well as relevant to the problem under study [30,31] where DN and AN refer to the solvent Lewis basicity and acidity; respectively [28]. $\mathrm{S}$ is the solvent bipolarity term; $\mathrm{P}$ is a measure of the susceptibility of the complex to solvation. $E_{B}, C_{B}$ and $E_{A}, C_{A}$ quantify the electrostatic and covalent contributions to the Lewis basicity and acidity; respectively [29-31]. For acceptor probes, (complexes 1 and 2), $\mathrm{E}_{\mathrm{B}}$ and $\mathrm{C}_{\mathrm{B}}$ solvent parameters are used in Equation 2. Nevertheless, $E_{A}$ and $C_{A}$ reflect the physicochemical acceptor parameters of the complex under investigation. However $\mathrm{E}_{\mathrm{A}}$ and $\mathrm{C}_{\mathrm{A}}$ solvent parameters were used as an alternative in case of complex 3 .

The following discussion examines the data of the current complexes. The overall picture which emerges from the MLRA based on Guttmann's donor-acceptor concept is considered followed by the unified solvent model proposed by Drago. The frequencies of $\mathrm{d}-\mathrm{d}$ absorption transition band $\left(v_{\max }\right)$ of the current complexes in various solvents (Table 4) are fitted in Equations 1 and 2. The Regression coefficients and constant values are shown in Table 6.

Fitting spectral data of the current complexes (Table 4) in Equation 1 indicates dependence of the $\mathrm{d}-\mathrm{d}$ absorption transitions on the $\mathrm{DN}$ and AN parameters. The relative percentage of the influences of DN and AN parameters on the $v_{\max }$ values were calculated from the coefficients $a$ and $b$, and found in the ranges $16.23-96.7 \%$ and $3.23-83.77 \%$; respectively. The data in Table 6 suggests that, the DN parameter of the solvent has the dominant contribution $(61.30-96.77 \%)$ in the shift of d-d absorption band of the perchlorate complexes 1, 2 and 4 . However, the AN parameter $(83.77 \%)$ is more pronounced than the DN parameter (16.23\%) in case of chloride complex 3. The negative signs of the coefficients $a$ and $b$ for the current complexes indicate a red shift as the Lewis acid- base interactions increases. Complexes 1 and 2 are highly sensitive towards the Lewis basicity of solvent than complex 4 as indicated from their contribution percentage of $\mathrm{DN}$ (89.7-96.8) for the former and $61.3 \%$ for the later.

Fitting the $v_{\max }$ data (Table 4) in Equation 2 indicates dependence of the observed spectral shifts on the dipolarity/polarizability parameter $\mathrm{P}(\mathrm{S})$ and both components of the Lewis acid-base quantification, $\mathrm{E}$ and $\mathrm{C}$ parameters. The regression coefficients reported in Table 6 indicate that, the shift of the $\mathrm{d}$ - $\mathrm{d}$ absorption transitions of the chloride complex 3 is mainly influenced by the specific term of solute-solvent interaction (contribution percentages, $96 \%$ ); in which the contribution of the covalency part $(\mathrm{C})$ is more pronounced than the electrostatic part (E). However the contributions of $\mathrm{E}$ (67.65 and 56.00\%) are more pronounced than $\mathrm{C}$ (11.7 and 3.3\%) for the perchlorate complexes 1 and 4, respectively; whereas in case of perchlorate complex 2, E smaller than $\mathrm{C}(22.40$ and $33.51 \%)$. In the same way the non-specific term plays a significance role on the d-d transition of complexes 2 and 4 than complex 1 .

The d-d transition band in the visible region of the electronic absorption spectrum of the investigated complexes is completely resolved, which allows an accurate determination of the band's oscillator strength $(f)$ as described earlier [8]. The oscillator strength, $f$, is a dimensionless quantity that is used to express the electronic transition probability [23]. Table 7 collects $f$-values of the present complexes, in several solvents.

Once more, the data in Table 7 reveals the dependence of the $\mathrm{d}$-d transitions on the Lewis acid base interactions of the current

\begin{tabular}{|c|c|c|c|c|c|c|c|c|c|}
\hline \multirow[t]{2}{*}{ No } & \multirow{2}{*}{$\begin{array}{l}\text { Complex } \\
\text { HDMCHD }\end{array}$} & \multicolumn{2}{|c|}{$v(C=0)$} & \multirow{2}{*}{$\begin{array}{c}C=C \\
1474\end{array}$} & \multicolumn{3}{|c|}{$\mathrm{v}\left(\mathrm{ClO}_{4}^{-}\right)$or } & \multirow{2}{*}{$\begin{array}{c}\mathrm{v}(\mathrm{Cu}-\mathrm{O}) \\
-\end{array}$} & \multirow{2}{*}{$\begin{array}{c}\mathrm{v}(\mathrm{Cu}-\mathrm{N}) \\
-\end{array}$} \\
\hline & & 1613 & 1582 & & - & - & - & & \\
\hline 1 & $\mathrm{Cu}_{2}(\mathrm{DMCHD})\left(\mathrm{Me}_{3} \mathrm{en}\right)_{2}\left(\mathrm{ClO}_{4}\right)_{3} \cdot 2 \mathrm{C}_{2} \mathrm{H}_{5} \mathrm{OH}$ & $1624(\mathrm{~m})$ & - & $1468(w)$ & 1141 & 1085 & 626 & 515 & $458(w)$ \\
\hline 2 & $\mathrm{Cu}_{2}(\mathrm{DMCHD})\left(\mathrm{Me}_{4} \mathrm{en}\right)_{2}\left(\mathrm{ClO}_{4}\right)_{3} \cdot 2 \mathrm{C}_{2} \mathrm{H}_{5} \mathrm{OH}$ & 1638 & 1570 & $1410(\mathrm{~s})$ & 1144 & 1090 & 627 & 525 & 478 \\
\hline 3 & {$\left[\mathrm{Cu}_{2}(\mathrm{DMCHD})\left(\mathrm{Me}_{4} \mathrm{en}\right)_{2} \mathrm{Cl}_{2}\right] \mathrm{Cl} \cdot 2 \mathrm{C}_{2} \mathrm{H}_{5} \mathrm{OH}$} & 1674 & $1602(s)$ & $1528(\mathrm{~m})$ & - & - & - & 568 & 500 \\
\hline 4 & $\mathrm{Cu}_{2}(\mathrm{DMCHD})\left(\mathrm{Me}_{5} \mathrm{dien}\right)_{2}\left(\mathrm{ClO}_{4}\right)_{3} \cdot 2 \mathrm{C}_{2} \mathrm{H}_{5} \mathrm{OH}$ & 1637 & 1618 & 1572 & 1143 & 1089 & - & 574 & 478 \\
\hline
\end{tabular}
$\mathrm{Cu}$ (II)-complexes with the solvent molecules as indicated from the

\begin{tabular}{|c|c|c|c|c|c|c|c|c|c|}
\hline No & Complex & Py & DMSO & DMF & $\mathrm{MeOH}$ & $\mathrm{Me}_{2} \mathrm{CO}$ & $\mathrm{MeCN}$ & 1.2DCE & $\mathrm{MeNO}_{2}$ \\
\hline 1 & $\mathrm{Cu}_{2}(\mathrm{DMCHD})\left(\mathrm{Me}_{3} \mathrm{en}\right)_{2}\left(\mathrm{ClO}_{4}\right)_{3} \cdot 2 \mathrm{C}_{2} \mathrm{H}_{5} \mathrm{OH}$ & 670 & 646 & 633 & 605 & 571 & 596 & 590 & 525 \\
\hline 2 & $\mathrm{Cu}_{2}(\mathrm{DMCHD})\left(\mathrm{Me}_{4} \mathrm{en}\right)_{2}\left(\mathrm{ClO}_{4}\right)_{3} \cdot 2 \mathrm{C}_{2} \mathrm{H}_{5} \mathrm{OH}$ & 664 & 646 & 632 & 614 & 576 & 588 & 595 & 525 \\
\hline 3 & {$\left[\mathrm{Cu}_{2}(\mathrm{DMCHD})\left(\mathrm{Me}_{4} \mathrm{en}\right)_{2} \mathrm{Cl}_{2}\right] \mathrm{Cl} \cdot 2 \mathrm{C}_{2} \mathrm{H}_{5} \mathrm{OH}$} & 749 & 709 & 696 & 661 & 678 & 685 & 620 & 691 \\
\hline 4 & $\begin{array}{c}\mathrm{Cu}_{2}(\mathrm{DMCHD}) \\
(\mathrm{Me} 5 \text { dien })_{2}\left(\mathrm{ClO}_{4}\right)_{3} \cdot 2 \mathrm{C}_{2} \mathrm{H}_{5} \mathrm{OH}\end{array}$ & 695 & 692 & 675 & 655 & 645 & 625 & 640 & 630 \\
\hline
\end{tabular}

Table 3: Characteristic infrared frequencies $\left(\mathrm{cm}^{-1}\right)$ and their tentative assignments of free HDMCHD ligand and its mixed ligand complexes

Table 4: Absorption maxima bands, $\lambda_{\text {max }} / \mathrm{nm}$ for the $\mathrm{Cu}_{2}(\mathrm{DMCHD})(\mathrm{am})_{2} \mathrm{X}_{3}$ complexes solutions in various solvents at $25^{\circ} \mathrm{C}$. 
Citation: Taha A, Ahmed HM (2015) Spectral, Electrochemical and Molecular Orbital Studies on a New Solvatochromic Binuclear Mixed Ligand Copper(II) Complexes. Mod Chem appl 3: 158. doi:10.4172/2329-6798.1000158

Page 5 of 8

\begin{tabular}{|c|c|c|c|c|c|c|c|}
\hline Chelate & $\mathrm{ClO}_{4}^{-}$ & $I^{-}$ & $\mathrm{Br}^{-}$ & $\mathrm{Cl}^{-}$ & $\mathbf{N}_{3}^{-}$ & $\mathrm{CF}_{3} \mathrm{SO}_{3}^{-}$ & $\mathrm{CO}_{3}^{-2}$ \\
\hline $\mathrm{DN}_{\mathrm{x}}($ anion $) / \mathrm{MeNO}_{2}$ & 8.44 & 28.9 & 33.7 & 36.2 & 34.3 & 16.9 & 13.3 \\
\hline $\mathrm{Cu}_{2}(\mathrm{DMCHD})\left(\mathrm{Me}_{3} \mathrm{en}\right)_{2}\left(\mathrm{ClO}_{4}\right)_{3} \cdot 2 \mathrm{C}_{2} \mathrm{H}_{5} \mathrm{OH}$ & 525 & 670 & 677 & 690 & 684 & - & - \\
\hline $\mathrm{Cu}_{2}(\mathrm{DMCHD})\left(\mathrm{Me}_{4} \mathrm{en}\right)_{2}\left(\mathrm{ClO}_{4}\right)_{3} 2 \mathrm{C}_{2} \mathrm{H}_{5} \mathrm{OH}$ & 567 & 647 & 707 & 705 & 608 & 635 & 573 \\
\hline
\end{tabular}

Table 5: Absorption maxima bands, $\lambda_{\text {max }} / \mathrm{nm}$ for the $\mathrm{Cu}_{2}(\mathrm{DMCHD})(\text { diam })_{2}\left(\mathrm{ClO}_{4}\right)_{3}$ complexes with various anions in $\mathrm{MeNO}_{2}$ solution at $25^{\circ} \mathrm{C}$.

\begin{tabular}{|c|c|c|c|c|c|c|c|c|c|c|c|c|}
\hline \multirow{3}{*}{$\begin{array}{c}\text { Complex } \\
\mathrm{Cu}_{2}(\mathrm{DMCHD})\left(\mathrm{Me}_{3} \mathrm{en}\right)_{2}\left(\mathrm{ClO}_{4}\right)_{3} \cdot 2 \mathrm{C}_{2} \mathrm{H}_{5} \mathrm{OH}\end{array}$} & \multicolumn{4}{|c|}{ MLRA using Gutmann parameter, Eqn. 2} & \multicolumn{5}{|c|}{$\begin{array}{l}\text { MLRA using Drago parameter, } \\
\text { Eqn. }\end{array}$} & \multicolumn{3}{|c|}{ Relative contrib. $\%$} \\
\hline & \multirow{2}{*}{$\begin{array}{c}\boldsymbol{v}_{s}^{0} / 10^{3} \\
19.86\end{array}$} & \multirow{2}{*}{$\begin{array}{c}\text { a } \\
-3.50 \\
(94.59)^{*}\end{array}$} & \multirow{2}{*}{$\begin{array}{c}\boldsymbol{b} \\
-0.20 \\
(5.41)^{*}\end{array}$} & \multirow{2}{*}{$\begin{array}{c}\mathbf{r} \\
0.97\end{array}$} & \multirow{2}{*}{$\begin{array}{c}w \\
18.40\end{array}$} & \multirow{2}{*}{$\begin{array}{c}P \\
0.468\end{array}$} & \multirow{2}{*}{$\begin{array}{c}E \\
-1.533\end{array}$} & \multirow{2}{*}{$\begin{array}{c}\boldsymbol{C} \\
-0.265\end{array}$} & \multirow{2}{*}{$\begin{array}{c}\mathbf{r} \\
0.99\end{array}$} & \multirow{2}{*}{$\begin{array}{c}\text { Non-specific } \\
20.65\end{array}$} & \multicolumn{2}{|c|}{ Specific } \\
\hline & & & & & & & & & & & 67.65 & 11.70 \\
\hline $\mathrm{Cu}_{2}(\mathrm{DMCHD})\left(\mathrm{Me}_{4} \mathrm{en}\right)_{2}\left(\mathrm{ClO}_{4}\right)_{3} \cdot 2 \mathrm{C}_{2} \mathrm{H}_{5} \mathrm{OH}$ & 19.72 & $\begin{array}{c}-3.69 \\
(95.35)^{\star}\end{array}$ & $\begin{array}{l}-0.18 \\
(4.65)^{\star}\end{array}$ & $\begin{array}{l}0.99 \\
0.99\end{array}$ & 14.39 & 0.745 & -0.378 & 0.566 & 0.97 & 44.1 & 22.4 & 33.51 \\
\hline$\left[\mathrm{Cu}_{2}(\mathrm{DMCHD})\left(\mathrm{Me}_{4} \mathrm{en}\right)_{2} \mathrm{Cl}_{2}\right] \mathrm{Cl} \cdot 2 \mathrm{C}_{2} \mathrm{H}_{5} \mathrm{OH}$ & 15.72 & $\begin{array}{c}-0.62 \\
(16.23)^{\star}\end{array}$ & $\begin{array}{c}-3.20 \\
(83.77)^{*}\end{array}$ & 0.998 & 15.32 & -0.23 & 2.18 & -3.10 & 0.99 & 4.0 & 39.50 & 56.30 \\
\hline $\mathrm{Cu}_{2}(\mathrm{DMCHD})(\mathrm{Me} 5 \mathrm{dien})_{2}\left(\mathrm{ClO}_{4}\right)_{3} \cdot 2 \mathrm{C}_{2} \mathrm{H}_{5} \mathrm{OH}$ & 16.47 & $\begin{array}{l}-2.075 \\
(61.30)^{\star}\end{array}$ & $\begin{array}{l}-1.031 \\
(38.70)^{\star}\end{array}$ & 0.98 & 13.78 & 0.50 & 0.69 & -0.041 & 0.97 & 40.70 & 56.00 & 3.30 \\
\hline
\end{tabular}

*Relative contribution percentage.

Table 6: Solvatochromic parameters of the $\mathrm{Cu}_{2}(\mathrm{DMCHD})(\mathrm{am})_{2} \mathrm{X}_{3}$ complexes, using Gutmann's and Drag's models (Equations 1and 2).

\begin{tabular}{|c|c|c|c|c|c|c|c|c|c|c|c|c|c|c|c|}
\hline \multirow[t]{2}{*}{ No. } & \multirow[t]{2}{*}{ Solvent/Complex } & \multicolumn{7}{|c|}{$F \times 103$} & \multicolumn{5}{|c|}{$F=f \circ+a D N+b A N$} & \multicolumn{2}{|c|}{ el.con } \\
\hline & & PY & DMSO & DMF & МeOH & $\mathrm{Me} 2 \mathrm{CO}$ & $\mathrm{MeCN}$ & $\mathrm{CH} 2 \mathrm{Cl} 2$ & $f \circ$ & $\mathbf{a}$ & b & $\mathbf{r}$ & $\mathbf{n}$ & DN & AN \\
\hline 1 & $\begin{array}{l}\mathrm{Cu}_{2}(\mathrm{DMCHD}) \\
\left(\mathrm{Me}_{3} \mathrm{en}\right) 2(\mathrm{ClO} 4)_{3} \cdot 2 \mathrm{C}_{2} \mathrm{H}_{5} \mathrm{OH}\end{array}$ & 24.827 & 24.523 & 25.027 & 25.531 & 27.745 & 25.916 & 28.194 & 28.16 & $\overline{0} .112$ & - & 0.93 & 6 & 100 & 0 \\
\hline 2 & $\begin{array}{l}\mathrm{Cu}_{2}(\mathrm{DMCHD}) \\
\left(\mathrm{Me}_{4} \mathrm{en}\right)_{2}\left(\mathrm{ClO}_{4}\right)_{3} \cdot 2 \mathrm{C}_{2} \mathrm{H}_{5} \mathrm{OH}\end{array}$ & 24.634 & 25.321 & 22.00 & 25.308 & 28.398 & 30.600 & 29.553 & 32.4 & -7.37 & $-\overline{4.64}$ & 0.99 & 5 & 61.4 & 38.6 \\
\hline 3 & $\begin{array}{l}{\left[\mathrm{Cu}_{2}(\mathrm{DMCHD})\left(\mathrm{Me}_{4} \mathrm{en}\right)_{2} \mathrm{Cl} 2\right]} \\
\mathrm{Cl} .2 \mathrm{C}_{2} \mathrm{H}_{5} \mathrm{OH}\end{array}$ & 14.126 & 14.018 & 14.280 & 15.521 & 14.659 & 15.445 & 16.548 & 16.2 & -3.24 & 1.33 & 0.92 & 7 & 70.9 & 29.1 \\
\hline 4 & $\begin{array}{l}\mathrm{Cu}_{2}(\mathrm{DMCHD}) \\
(\text { Me5dien })_{2}\left(\mathrm{ClO}_{4}\right)_{3} \cdot 2 \mathrm{C}_{2} \mathrm{H}_{5} \mathrm{OH}\end{array}$ & 11.3 & 9.581 & 8.706 & 9.586 & 9.734 & 9.242 & 8.633 & 8.3 & 3.25 & $\overline{-}-68$ & 0.99 & 5 & 84.3 & 15.7 \\
\hline
\end{tabular}

Table 7: Oscillator strength $(f)$ of $d-d$ transition absorption bands of the $\mathrm{Cu}_{2}(\mathrm{DMCHD})(\mathrm{am})_{2} \mathrm{X}_{3}$ complexes.

linear plots of the $f$-values versus the Lewis basicity (DN) and Lewis acidity (AN) of solvent: $f=\mathrm{f}_{0}+\mathrm{a} \mathrm{DN}+\mathrm{b} \mathrm{AN}$, the multi-parametric linear regression data were collected in Table 7 . The intercept $\left(\mathrm{f}_{0}\right)$ represent the extrapolated oscillator strength, which was found to be higher for square planar diamine complexes 1 and 2 than the five coordinated, chloro of diamine and the perchlorate of triamine, complexes 3 and 4. For the same complex cation, $\left[\mathrm{Cu}_{2}(\mathrm{DMCHD})\left(\mathrm{Me}_{4} \mathrm{en}\right)_{2}\right]^{3+}$, as the coordination ability of Lewis base increases f-values decreases.

\section{Electrochemical studies}

Cyclic voltammetric studies were performed for some copper(II) complexes 2 and 3 using a platinum microelectrode, of $1.0 \mathrm{mM}$ $\mathrm{L}^{-1}$ complex solutions in different solvents and $0.1 \mathrm{M} \mathrm{L}^{-1} \mathrm{Bu}_{4} \mathrm{ClO}_{4}$ as supporting electrolyte at scanning rate of $100 \mathrm{mV} \mathrm{s}^{-1}$, ferrocine/ ferrocinium $\left(\mathrm{Fc} / \mathrm{Fc}^{+}\right)$and bis(biphenyl)chromium $(\mathrm{I}) /(0)$ were used as internal standards for assignment of the potential values, the experimental data are given in Table 8. Since the ligands used in this work are not reversibly oxidized or reduced at the applied potential range values, the redox processes are assigned to the metal centers only. The reduction process of the investigated complexes in all solvents exhibited a quasi-reversible or quasi-irreversible, redox associated with a two-electron reduction, and mainly diffusion controlled as indicated from the linear dependence of the current peak on the square root of the scan rate [32-34].

Taking into account the cyclic voltammetric behavior of $\left[\mathrm{Cu}_{2}(\mathrm{DMCHD})\left(\mathrm{Me}_{4} \text { en }\right)_{2} \mathrm{Cl}_{2}\right] \mathrm{Cl}$ complex 3 , in DMF solution (Figure 2) one can propose the following mechanism consisting of electrode and chemical reactions:

(a) the cathodic peak can be assigned to the cathodic reduction 
Citation: Taha A, Ahmed HM (2015) Spectral, Electrochemical and Molecular Orbital Studies on a New Solvatochromic Binuclear Mixed Ligand Copper(II) Complexes. Mod Chem appl 3: 158. doi:10.4172/2329-6798.1000158

Page 6 of 8

\begin{tabular}{|c|c|c|c|c|c|c|c|c|}
\hline \multirow[t]{2}{*}{ Solvent } & \multicolumn{4}{|c|}{$\mathrm{Cu}_{2}(\mathrm{DMCHD})\left(\mathrm{Me}_{4} \text { en }\right)_{2}\left(\mathrm{ClO}_{4}\right)_{3}$} & \multicolumn{4}{|c|}{$\mathrm{Cu}_{2}(\mathrm{DMCHD})\left(\mathrm{Me}_{4} \text { en }\right)_{2}\left(\mathrm{Cl}_{3}\right)$} \\
\hline & $E_{p c 1}$ & $\mathrm{E}_{\mathrm{pc} 2}$ & $\mathrm{E}_{\mathrm{pa} 1}$ & $\mathrm{E}_{\mathrm{pa} 2}$ & $E_{p c 1}$ & $\mathrm{E}_{\mathrm{pc} 2}$ & $\mathrm{E}_{\mathrm{pa} 1}$ & $\mathrm{E}_{\mathrm{pa} 2}$ \\
\hline $\mathrm{MeNO}_{2}$ & 0.83 & - & 0.52 & - & 0.80 & 0.87 & 0.015 & - \\
\hline $\mathrm{MeCN}$ & 0.48 & - & 0.149 & - & 0.49 & 0.58 & 0.12 & - \\
\hline $\mathrm{Fa}$ & 0.62 & 0.91 & 0.225 & 0.62 & 0.61 & - & 0.62 & - \\
\hline DMF & 0.914 & 0.742 & 0.127 & - & 0.632 & - & 0.567 & 0.262 \\
\hline DMSO & 0.933 & 0.723 & 0.713 & 0.328 & 0.728 & 0.908 & 0.377 & 0.327 \\
\hline
\end{tabular}

Table 8: Electrochemical data for the redox processes of $\mathrm{Cu}_{2}(\mathrm{DMCHD})(\mathrm{diam})_{2} \mathrm{X}_{3}$ in various solvents potentials $\mathrm{E} / \mathrm{V}$ vs. bis(biphenyl)-chromium(1) at (pt) ref electrode

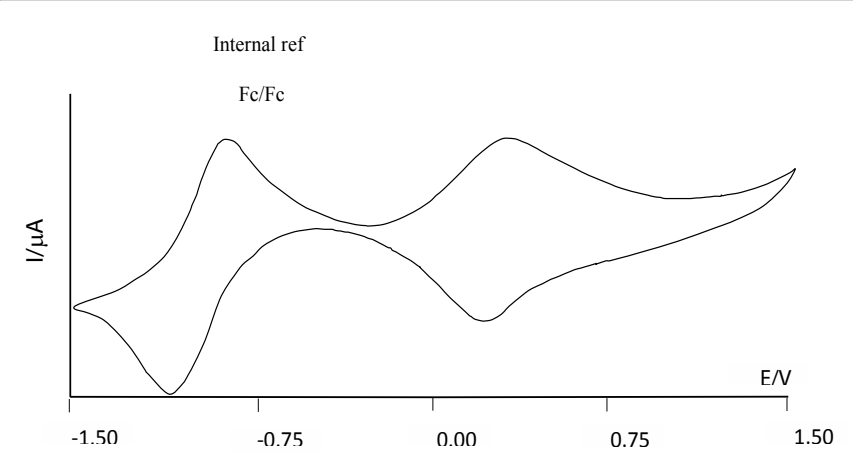

Figure 2: Cyclic voltammograms recorded with a platinum microelectrode for the DMF solution of $1.0 \times 10^{-3} \mathrm{~mol} \mathrm{~L}^{-1}\left[\mathrm{Cu}_{2}(\mathrm{DMCHD})\left(\mathrm{Me}_{4} \text { en }\right)_{2}\right]\left(\mathrm{ClO}_{4}\right)_{3} 2 \mathrm{C}_{2} \mathrm{H}_{5} \mathrm{OH}$ complex, 18 solutions in presence of $0.1 \mathrm{~mol} \mathrm{~L}^{-1} \mathrm{Bu}_{4} \mathrm{NCO}_{4}$ as supporting electrolyte and scan rate of $100 \mathrm{mVs}^{-1}$.

of the dicopper (II) complex to the dicopper (I) complex in a quasirreversible mechanism.

$$
\mathrm{Cu}^{\mathrm{II}} \mathrm{Cu}^{\mathrm{II}} \leftrightharpoons \mathrm{Cu}^{\mathrm{I}} \mathrm{Cu}^{\mathrm{I}}
$$

or

(b) Dissociation of the dicopper (II) into a mononuclear complex in solution first, followed by a reduction process for the product; according to the following sequences:

The anodic peak can be assigned to the anodic oxidation of the complex $\mathrm{Cu}(0)$, if this one could exist for very short time, to complex $\mathrm{Cu}(\mathrm{I})$ :

\section{$\mathrm{Cu}(\mathrm{I})$-complex $+\mathrm{e}^{-} \rightarrow \mathrm{Cu}(0)$-complex}

The decomplexation reaction is a chemical reaction occurring because the $\mathrm{Cu}(0)$ atom is unable to keep the ligands in a coordination arrangement:

\section{$\mathrm{Cu}(0)$-complex $\rightarrow \mathrm{Cu}(0)+$ ligands}

This chemical reaction is fast enough in order to decrease the height of the corresponding anodic peak in which complex $\mathrm{Cu}(0)$ is involved.

The very prominent anodic peak, probably due to the anodic oxidation of the complex $\mathrm{Cu}(\mathrm{I})$ to complex $\mathrm{Cu}(\mathrm{II})$.

\section{$\mathrm{Cu}(\mathrm{I})$-complex $\rightarrow \mathrm{Cu}(\mathrm{II})$-complex $+\mathrm{e}^{-}$}

So that one may conclude that the mechanism of the single cyclic voltammetry behaviour of the complex $\mathrm{Cu}$ (II) is described by an EECE or EEC mechanism. ( $\mathrm{C}=$ chemical complication following the charge transfer E), rather than a simple EE mechanism. It is more likely that, according to the Marcus theory, the activation barrier to electron transfer is increased, slowing down the rate of heterogeneous charge transfer, i.e., causing distinct deviation from the pure reversible character of the charge transfer [35].

The potential values of the redox peaks $\left(\mathrm{E}_{\mathrm{pc}}\right.$ and $\left.\mathrm{E}_{\mathrm{pa}}\right)$ of the investigated complexes in different solvents are given in Table 8. The $\mathrm{E}_{\mathrm{pc}}$ potentials for the binuclear perchlorate and chloride $\mathrm{Cu}$ (II) complexes depend again on the Lewis acid-base solvent's properties. The trend of data also agrees well with the visible absorption spectral results in various solvents where, complex 2: $\mathrm{Epc}_{1} / \mathrm{v}=6.562-3.63 \times 10^{-4}$ $v / \mathrm{cm}^{-1}, \mathrm{r}=0.94$ (4 points, except $\mathrm{MeNO}_{2}$ ); and Epa1/v $=1.716+1.16 \times$ $10^{-4} \mathrm{v} / \mathrm{cm}^{-1}, \mathrm{r}=0.93$ (4 points, except DMSO)

However complex $3 \mathrm{Cu}_{2}(\mathrm{DMCHD})\left(\mathrm{Me}_{4} \mathrm{en}\right)_{2} \mathrm{Cl}_{3}: \mathrm{Epcl} / \mathrm{v}=7.7 .78$ $4.78 \times 10^{-4} \mathrm{v} / \mathrm{cm}^{-1}, \mathrm{r}=0.99$ (3 points, except $\mathrm{MeNO}_{2}$ and $\mathrm{Fa}$ ); and Epa ${ }_{1}$ $\mathrm{V}=8.26+5.73 \times 10^{-4} \mathrm{v} / \mathrm{cm}^{-1}, \mathrm{r}=0.99$ (3 points, except DMF and DMSO)

$\mathrm{T}$ he combination of electrochemical and spectroscopic studies enables one to investigate the axial ligation of the solvatochrmic complexes in detail that can utilized to achieve a microscopic understanding of the specific and non-specific Lewis-acid base interactions of the current $\mathrm{Cu}(\mathrm{II})$-complexes with solvent molecules.

\section{Molecular orbital calculations}

Table 9 shows the structural parameters data of the free ligands and their $\mathrm{Cu}(\mathrm{II})$-complexes as calculated by means of a semiempirical molecular orbital calculations at the PM3 level provides by the hyperchem 7.52 program. The calculated energies of the Frontier orbitals, lowest unoccupied $\left(\mathrm{E}_{\mathrm{LUMO}}\right)$ and highest occupied molecular orbitals $\left(\mathrm{E}_{\text {НОмо }}\right)$ and $\mathrm{E}_{\text {gap }}\left(\mathrm{E}_{\text {gap }}=\mathrm{E}_{\text {Lumo }}-\mathrm{E}_{\text {HОмО }}\right)$ of the ligands and their complexes are correlated with the current experimental data (Tables 3 and 4): Egap/eV=9.597-0.0157 $\Delta\left({ }_{\mathrm{C}=\mathrm{O}-\mathrm{C}=\mathrm{C}}\right) / \mathrm{cm}^{-1}, \mathrm{r}=0.92$,

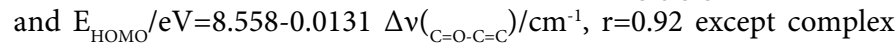
1. The negative slope of these linear relationships reveal increasing of both Egap and $\mathrm{E}_{\text {номо }}$ accompanied by decreasing the separation in frequencies between the carbonyl group, $v_{\mathrm{C}=\mathrm{O}}$ and adjacent $v_{\mathrm{C}=\mathrm{C}}$. This finding further emphasized by the negative slope of the linear relationship of the calculated $\mathrm{E}_{\text {номо }}$ (Table 9) versus the $\mathrm{d}$ - $\mathrm{d}$ transition $v_{\text {max }}: \mathrm{E}_{\text {номо }} / \mathrm{eV}=14.127-4.54 \times 10^{-4} v_{\max } / \mathrm{cm}^{-1}, \mathrm{r}=0.92$, except complex 1. The negative slope recommends again increasing of $\mathrm{E}_{\text {номо }}$ was accompanied by red shift of $\mathrm{d}$-d band. Figure 3 shows the optimized structure of the current complex 1 as an example.

Biological activity studies: Table 10 , summarized the biological activity of $\mathrm{Cu}_{2}(\mathrm{DMCHD})\left(\mathrm{Me}_{5} \mathrm{dien}\right)_{2}\left(\mathrm{ClO}_{4}\right)_{2}$ complex. Investigation 
Citation: Taha A, Ahmed HM (2015) Spectral, Electrochemical and Molecular Orbital Studies on a New Solvatochromic Binuclear Mixed Ligand Copper(II) Complexes. Mod Chem appl 3: 158. doi:10.4172/2329-6798.1000158

Page 7 of 8

was carried out against the sensitive organisms Staphylococcus aureus (ATCC 25923) and Bacillus subtilis (ATCC 6635) as Gram-positive bacteria, Escherichia coli (ATCC 25922) and Salmonella typhimurium (ATCC 14028) as Gram-negative bacteria, yeast; Candida albicans (ATCC 10231) and fungus; Aspergillus fumigates as described elsewere [36]. Inspection of the data reveals that the metal complex exhibited intermediate activity towards the Gram- positive bacteria Bacillus subtilis (ATCC 6635), also intermediate activity towards the Gramnegative bacteria Salmonella typhimurium (ATCC 14028). However, low antimicrobial activity was observed against Yeasts and Fungi; similar to that observed earlier for $\mathrm{Cu}(\mathrm{DMCHD})\left(\mathrm{Me}_{5} \operatorname{dien}\right)\left(\mathrm{NO}_{3}\right)[11]$.
A newly compounds have been synthesized and characterized on the basis of spectral, conductance, magnetic and electrochemical studies on the complexes were carried out in solution and in solid state; UV-visible spectra on the solution of the complexes in various solvents are found to be depending upon the type of solvent. The absorption coefficient spectrum in the UV-Vis region shows absorption bands and generally interpreted in terms of $\pi-\pi^{\star}$ excitation. The metal complex $\mathrm{Cu}_{2}(\mathrm{DMCHD})\left(\mathrm{Me}_{5} \text { dien }\right)_{2}\left(\mathrm{ClO}_{4}\right)_{2}$ showed intermediate activity toward the Gram- positive and Gram-negative bacteria, and low antimicrobial activity against yeasts and fungi.

\section{References}

\section{Conclusion}

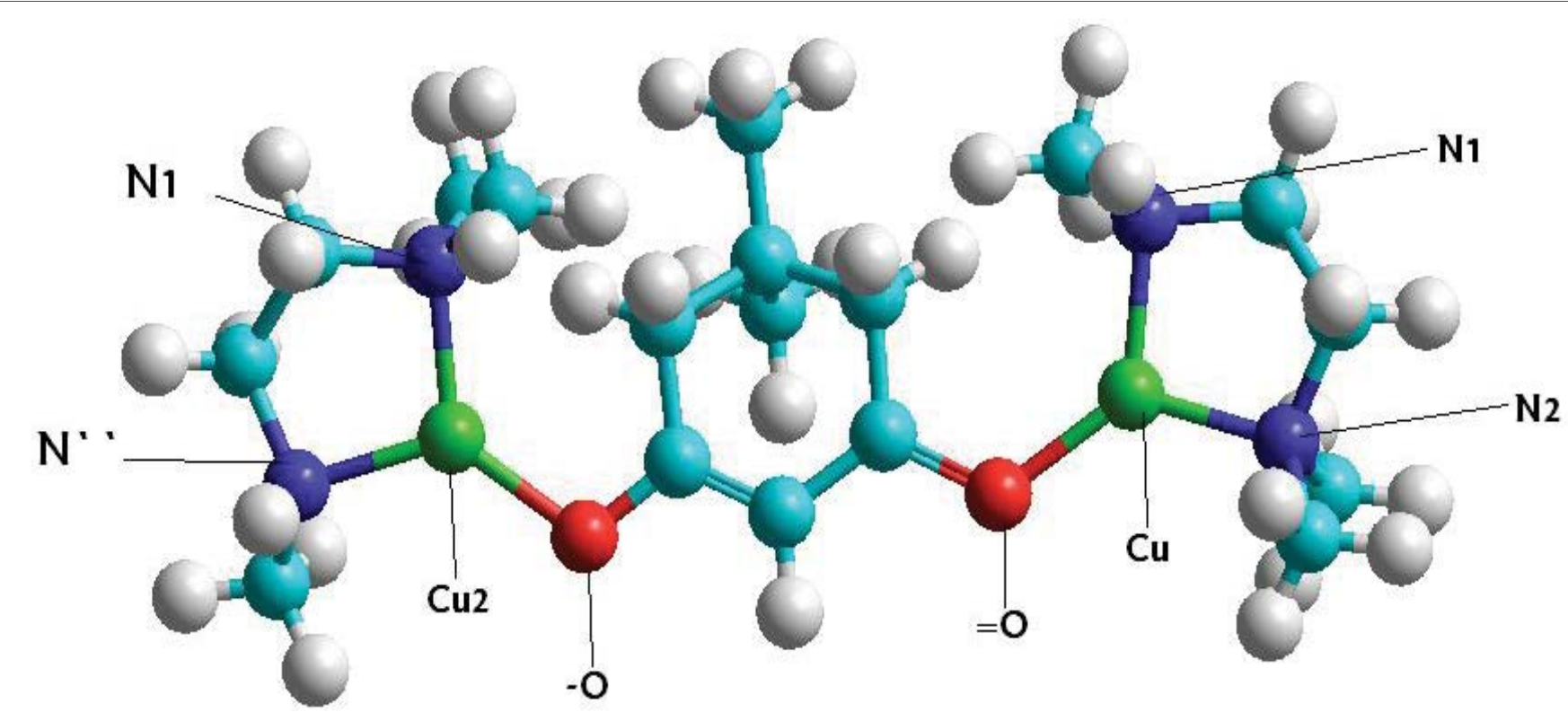

Figure 3: Optimized structure of complex $1\left\{\mathrm{Cu}_{2}(\mathrm{DMCHD})\left(\mathrm{Me}_{3} \mathrm{en}\right)_{2}\right\}\left(\mathrm{ClO}_{4}\right)_{3} \cdot 2 \mathrm{C}_{2} \mathrm{H}_{5} \mathrm{OH}$.

\begin{tabular}{|c|c|c|c|c|c|c|c|c|c|c|}
\hline No & $\begin{array}{l}\text { Organic ligand } \\
\text { and complex }\end{array}$ & $\begin{array}{c}\mathrm{E}_{\mathrm{tot}} \\
\mathrm{Kcal} / \mathrm{mol}\end{array}$ & $\begin{array}{l}\text { Dipole } \\
\text { moment }\end{array}$ & $\begin{array}{c}\Delta \mathrm{Hf} \\
\mathrm{Kcal} / \mathrm{mol}\end{array}$ & $\begin{array}{l}\text { Electr E } \\
\text { Kcal/mol }\end{array}$ & $\begin{array}{l}\text { Nuclear E } \\
\mathrm{Kcal} / \mathrm{mol}\end{array}$ & $\begin{array}{l}\text { Binding E } \\
\mathrm{Kcal} / \mathrm{mol}\end{array}$ & $E_{\text {homo }}$ ev & $E_{\text {lumo }}$ ev & $\Delta$ Egap \\
\hline$A$ & $\mathrm{Me}_{4}$ en & -29581.82 & 1.20 & -13.30 & -158075.95 & 128494.13 & -2098.27 & -8.981 & 2.388 & 11.369 \\
\hline $\mathrm{B}$ & $\mathrm{Me}_{3} \mathrm{en}$ & -26136.84 & 1.74 & -11.45 & -128743.73 & 102606.88 & -1821.32 & -9.092 & 2.422 & 11.514 \\
\hline $\mathrm{C}$ & Dimedone free (HDMCHD) & -39685.20 & 4.94 & -90.39 & -204106.53 & 164421.32 & -2201.85 & -9.712 & -0.014 & 9.698 \\
\hline $\mathrm{D}$ & $\mathrm{Me}_{5}$ dien & -44015.22 & 2.40 & -16.52 & -284075.25 & 240059 & -30092.00 & -8.850 & 2.270 & 11.12 \\
\hline 1 & {$\left[\mathrm{Cu}_{2}(\mathrm{DMCHD})\left(\mathrm{Me}_{3} \mathrm{en}\right)_{2} \mathrm{ClO}_{4}\right.$} & -146288.39 & $6 . .90$ & -219.03 & -1130492.39 & 984204.5 & -6059.55 & -0.661 & 1.971 & 2.632 \\
\hline 2 & $\mathrm{Cu}_{2}(\mathrm{DMCHD})\left(\mathrm{Me}_{4} \mathrm{en}\right)_{2}(\mathrm{ClO} 4)_{3}$ & $-153186 . .66$ & 3.715 & -231.38 & -1264009.33 & 1110822.65 & -6622.08 & -5.314 & 1.026 & 6.34 \\
\hline 3 & {$\left[\mathrm{Cu}_{2}(\mathrm{DMCHD})\left(\mathrm{Me}_{4} e n\right)_{2} \mathrm{Cl}_{2}\right] \mathrm{Cl}$} & -175811.37 & 15.85 & -255.50 & -1576159.37 & 1400348.00 & -6837.38 & -7.190 & -0.5448 & 6.646 \\
\hline 4 & $\mathrm{Cu}_{2}(\mathrm{DMCHD})\left(\mathrm{Me}_{5} \mathrm{dien}\right)_{2}\left(\mathrm{ClO}_{4}\right)_{3}$ & -110636.36 & 5.871 & -107.24 & -943728.00 & 833091.93 & -5322.66 & -7.439 & 1.467 & 8.906 \\
\hline
\end{tabular}

Table 9: Structural parameters of the organic ligands and their metal complexes using hyperchem 7.5 at pm3 level. 
Citation: Taha A, Ahmed HM (2015) Spectral, Electrochemical and Molecular Orbital Studies on a New Solvatochromic Binuclear Mixed Ligand Copper(II) Complexes. Mod Chem appl 3: 158. doi:10.4172/2329-6798.1000158

Page 8 of 8

\begin{tabular}{|c|c|c|c|c|c|c|c|c|c|c|c|c|}
\hline \multirow[b]{2}{*}{ Organism } & \multicolumn{4}{|c|}{ Gram-positive bacteria } & \multicolumn{4}{|c|}{ Gram-negative bacteria } & \multicolumn{4}{|c|}{ Yeasts and Fungi" } \\
\hline & \multicolumn{2}{|c|}{$\begin{array}{c}\text { Staphylococcus } \\
\text { aureus } \\
\text { (ATCC 25923) }\end{array}$} & \multicolumn{2}{|c|}{$\begin{array}{l}\text { Bacillus subtilis } \\
\text { (ATCC 6635) }\end{array}$} & \multicolumn{2}{|c|}{$\begin{array}{c}\text { Salmonella } \\
\text { typhimurium } \\
\text { (ATCC 14028) }\end{array}$} & \multicolumn{2}{|c|}{$\begin{array}{l}\text { Escherichia coli } \\
\text { (ATCC 25922) }\end{array}$} & \multicolumn{2}{|c|}{$\begin{array}{l}\text { Candida albicans } \\
\text { (ATCC 10231) }\end{array}$} & \multicolumn{2}{|c|}{ Aspergillus fumigatus } \\
\hline Concentration & $1 \mathrm{mg} / \mathrm{ml}$ & $0.5 \mathrm{mg} / \mathrm{ml}$ & $\begin{array}{c}1 \mathrm{mg} / \\
\mathrm{ml}\end{array}$ & $0.5 \mathrm{mg} / \mathrm{ml}$ & $1 \mathrm{mg} / \mathrm{ml}$ & $0.5 \mathrm{mg} / \mathrm{ml}$ & $1 \mathrm{mg} / \mathrm{ml}$ & $0.5 \mathrm{mg} / \mathrm{ml}$ & $1 \mathrm{mg} / \mathrm{ml}$ & $0.5 \mathrm{mg} / \mathrm{ml}$ & $1 \mathrm{mg} / \mathrm{ml}$ & $0.5 \mathrm{mg} / \mathrm{ml}$ \\
\hline $\mathrm{Cu}(\mathrm{DMCHD})\left(\mathrm{Me}_{5} \mathrm{dien}\right)\left(\mathrm{NO}_{3}\right)$ & $10 \mathrm{~L}$ & $7 \mathrm{~L}$ & 131 & 91 & $12 \mathrm{~L}$ & $8 \mathrm{~L}$ & $15 I$ & $11 \mathrm{I}$ & $9 \mathrm{~L}$ & $7 \mathrm{~L}$ & $10 \mathrm{~L}$ & $6 \mathrm{~L}$ \\
\hline Control ${ }^{\#}$ & 35 & 26 & 35 & 25 & 36 & 28 & 38 & 27 & 35 & 28 & 37 & 26 \\
\hline
\end{tabular}

"Identified on the basis of routine cultural, morphological and microscopical characteristics.

L: Low activity=Mean of zone diameter $\leq 1 / 3$ of mean zone diameter of control.

I: Intermediate activity=Mean of zone diameter $\leq 2 / 3$ of mean zone diameter of control.

$\mathrm{H}$ : High activity=Mean of zone diameter $>2 / 3$ of mean zone diameter of control.

\#Chloramphenicol in the case of Gram-positive bacteria, cephalothin in the case of Gram-negative bacteria and cycloheximide in the case of fungi.

Table 10: Antimicrobial activity of $\mathrm{Cu}_{2}(\mathrm{DMCHD})\left(\mathrm{Me}_{5} \text { dien }\right)_{2}\left(\mathrm{ClO}_{4}\right)_{3} 2 \mathrm{C}_{2} \mathrm{H}_{5} \mathrm{OH}$

1. Linert W, Fukuda Y, Camard A (2001) Chromotropism of coordination compounds and its applications in solution. Coord Chem Rev 218: 113-152.

2. Soliman AA, Taha A, Linert W (2006) Spectral and thermal study on the adduct formation between square planar nickel(II) chelates and some bidentate ligands. Spectrochim Acta A Mol Biomol Spectrosc 64: 1058-1064.

3. Kuzniarska-Biernacka I, Bartecki A, Kurzak K (2003) UV-Vis-NIR spectroscopy and colour of bis(N-phenylsalicylaldiminato)cobalt(II) in a variety of solvents. Polyhedron 22: 997-1007.

4. Golchoubian H, Moayyedi G, Bruno G, Rudbari HA (2011) Syntheses and characterization of mixed-chelate copper(II) complexes containing differen counter ions; spectroscopic studies on solvatochromic properties. Polyhedron 30: $1027-1034$

5. Ashraf AM, Mohammed JM, Ismail Y (2012) Synthesis, Characterization and Biological Studies of 2-(4-Nitrophenylaminocarbonyl)Benzoic Acid and its Complexes With $\mathrm{Cr}(\mathrm{III}), \mathrm{Co}(\mathrm{II}), \mathrm{Ni}(\mathrm{II}), \mathrm{Cu}(\mathrm{II})$ and $\mathrm{Zn}(\mathrm{II})$. Iran J Chem and Chem Eng 31: 9-14.

6. Linert W, Taha A (1993) Spectroscopic, Thermodynamic and Quantum Mechanical Studies on Solvatochromic Mixed Ligand Copper(II)-Chelates. J Coord Chem 29: 265-276.

7. Taha A (2001) Spectroscopic and Molecular Orbital Studies of Chromotropic Ternary Complexes of Copper(II) with Thenoyltrifluoroacetone and Diamine Derivatives. Synth React Inorg Metal Org 31: 227-238.

8. Taha A (2001) Spectroscopic and electrochemical studies on the chromotropism of ternary copper(II) complexes. New J Chem 25: 853-858.

9. Taha A (2003) Spectral, electrochemical and molecular orbital studies on solvatochromic mixed ligand copper(II) complexes of malonate and diamine derivatives. Spectrochim Acta A Mol Biomol Spectrosc 59: 1373-1386.

10. Taha A (2003) Spectroscopic studies on chromotropic mixed-ligand copper(II) complexes containing o-hydroxy benzoyl derivatives and dinitrogen bases. Spectrochim Acta A Mol Biomol Spectrosc 59: 1611-1620.

11. Taha A, Farag AA, Ammar AH, Ahmed HM (2014) Structural, molecular orbital and optical characterizations of solvatochromic mixed ligand copper(II) complex of 5,5-Dimethyl cyclohexanate 1,3-dione and N,N,N',N'N"pentamethyldiethylenetriamine. Spectrochim Acta A Mol Biomol Spectrosc 122: 512-520.

12. Taha A (2001) Metal Complexes of Triazine Schiff Bases: Synthetic Thermodynamic, Spectroscopic, and Electrochemical Studies on Complexes of some Divalent and Trivalent Metal lons of 3-(A-Benzoylbenzylidenhydrazino)5,6-Diphenyl-1,2,4-Triazine. Synth React Inorg Met-Org Chem 31: 205-218.

13. Linert W, Taha A, Jameson RF (1992) The Electrochemical Behaviour of Mixed Nickel(II)-Chelates in Nonaqueous Solvents. J Coord Chem 25: 29-41.

14. Kucharsky J, Safarik L (1965) Titrations in Nonaqueous Solvents. Elsevier, Amsterdam, Netherlands.

15. Dutt NK, Sarma UUM (1975) Chemistry of lanthanous-XL. Solution stabilities of lanthanide ions with dimedone (5,5-dimethyl 1,3-cyclohexanedione). J Inorg Nucl Chem 37: 606-607.

16. Frankel LS, Stengle TR, Langford $\mathrm{CH}$ (1968) Preferential solvation of Co2 and $\mathrm{Ni2}^{+}$ions in mixed solvents: n.m.r. methods. Can J Chem 46: 3183-3187.
17. Dutt NK, Sanyal S, Sarma UUM (1972) Chemistry of lanthanons-XXXV: Formation constants of rare-earth elements with a few oxygen donating ligands. J Inorg Nucl Chem 34: 2261-2264.

18. Nakamoto K (1986) Infrared and Raman Spectra of Inorganic and Coordination (4thedn) Wiley-Interscience New York, USA.

19. Linert W, Jameson RF, Taha A (1993) Donor numbers of anions in solution: the use of solvatochromic Lewis acid-base indicators. J Chem Soc Dalton Trans 1993: 3181-3186.

20. Geary WJ (1971) The use of conductivity measurements in organic solvents for the characterization of coordination compounds. Coord Chem Rev 7: 81-122.

21. Huheey JE, Keiter EA, Keiter RL (1993) Inorganic Chemistry: Principles of Structures and Reactivity. (4thedn) Pearson Education Inc., USA.

22. Lever ABP (1984) Inorganic Electronic Spectroscopy. (2ndedn) Elsevier, Amsterdam, Netherlands.

23. Fukuda Y, Sone K (1987) Inorganic Thermochromism. Inorganic Chemistry Concepts. Springer-Verlag Berlin, Heidelberg, Germany.

24. O'Sullivan C, Murphy G, Murphy B, Hathaway B (1999) Crystal structures, electronic properties and structural pathways of thirty $\left[\mathrm{Cu}(\mathrm{bipy})_{2} \mathrm{X}\right][\mathrm{Y}]$ complexes, where $\mathrm{X}=\mathrm{Cl}^{-}, \mathrm{Br}$ or $\mathrm{I}^{-}$. J Chem Soc Dalton Trans 2: 1835-1844.

25. Soukup RW, Sone K (1987) (Acetylacetonato)(N,N,N',N'tetramethylethylenediamine)copper(II) Tetraphenylborate as a Solvent Basicity Indicator. Bull Chem Soc Jpn 60: 2286-2288.

26. Taha A, Gutmann V, Linert W (1991) Spectroscopic and thermodynamic studies on solvatochromic nickel(II) complexes. Monatsh Chem 122: 327-339.

27. Gutmann V (1978) The Donor-Acceptor Approach to Molecular Interactions Plenum Press, New York, USA

28. Drago RS (1980) The interpretation of reactivity in chemical and biologica systems with the $E$ and $C$ model. Coord Chem Rev 33: 251-277.

29. Drago RS, Ferris DC, Wong N (1990) A method for the analysis and prediction of gas-phase ion-molecule enthalpies. J Am Chem Soc 112: 8953-8961.

30. Drago RS (1992) A unified scale for understanding and predicting non-specific solvent polarity: a dynamic cavity model. J Chem Soc Perkin Trans 2: 1827 1838.

31. Gritzner G, Kuta J (1982) Recommendations on reporting electrode potentials in nonaqueous solvents. J Appl Chem 54: 1527-1532.

32. Gritzner G, Kuta J (1984) Recommendations on reporting electrode potentials in nonaqueous solvents (Recommendations 1983). J Appl Chem 56: 461-466.

33. Gritzner G (1986) Solvent effects on half-wave potentials. J Phy Chem 90: 5478-5485.

34. Mabbott GA (1983) An introduction to cyclic voltammetry. J Chem Edu 60: 697

35. Nakamura M, Okawa H, Kida S (1982) Binuclear metal complexes. XLVI[1] Electronic and electrochemical properties of copper(II)M(II) binuclear complexes of $\mathrm{N}, \mathrm{N}^{\prime}$-bis(5-t-butylsalicylidene)alkanediamines. Inorg Chim Acta 62: $201-205$

36. Vogel Al (1978) Vogel's textbook of quantitative inorganic analysis, including elementary instrumental analysis. (4thedn) Longman, London. 